\title{
Subsurface Shallow Modelling Based on Resistivity Data in the Hot Springs Area of Libungo Geothermal, Gorontalo, Indonesia
}

\author{
Intan Noviantari Manyoe ${ }^{1, *}$, Ronal Hutagalung ${ }^{1}$ \\ ${ }^{I}$ Geological Engineering Major, Faculty of Mathematics and Natural Science, Universitas Negeri Gorontalo, Gorontalo, Indonesia.
}

* Corresponding author : intan.manyoe@ung.ac.id

Tel.: +62 81280023410

Received: May 29, 2020; Accepted: Jun 18, 2020.

DOI 10.25299/jgeet.2020.5.2.5094

\begin{abstract}
Volcano-tectonic events in Libungo can be the cause of the presence of geothermal potential. There is no detailed research on shallow subsurface conditions in Libungo that can show the distribution of subsurface fluids. This research aims to create a shallow subsurface model of the Libungo geothermal area based on resistivity data. Resistivity data collection was carried out in the Libungo hot springs area. The electrode configuration used is the Schlumberger configuration. The variation in resistivity values is calculated using current data, potential difference data and geometry factors. The results of the calculation of the resistivity values variation are plotted versus depth. Variations of resistivity value versus depth are then displayed in the form of a single log, lithology distribution and 3D lithology model. The results showed that the shallow subsurface of the Libungo geothermal area was composed of andesite, volcanic breccia, silty clay and clay. Andesite in the research area has resistivity values ranging from $320-349 \Omega \mathrm{m}$, has slightly fracture and is andesite dry. Volcanic breccia has a resistivity value of $177-198 \Omega \mathrm{m}$, has a well to slightly fracture and is a volcanic breccia moist. Silty clay has a resistivity value of $3.25-37.99 \Omega \mathrm{m}$ and is a wet to moist silty clay. Clay has resistivity values in the range $1.56-2.78 \Omega \mathrm{m}$ and is wet to moist clay. Fluid distribution in the shallow subsurface area occurs in volcanic breccia, silty clay and clay. Shallow subsurface fluids accumulate mostly in the northern part of the Libungo geothermal area.
\end{abstract}

Keywords: Fracture, Fluids, Thermal, Lithology, Schlumberger.

\section{Introduction}

Geothermal potential in Indonesia is one of the largest in the world. Indonesia has abundant geothermal potential with 331 potentials spread from Sabang to Merauke (Direktorat Panas Bumi, 2017). Geothermal potential can be used directly or indirectly and has implications for improving the economic community. Gorontalo is one of the provinces in Indonesia, which has geothermal potential. All regencies in Gorontalo have geothermal potential, but the greatest geothermal potential is accumulated in eastern Gorontalo at Suwawa area.

Suwawa area consists of the Lombongo geothermal area, Pangi geothermal area, Libungo geothermal area, Tulabolo Timur geothermal area and Hungayono geothermal area. Various geothermal studies have been carried out in the Suwawa area in terms of geology, geophysics and geochemistry (Direktorat Panas Bumi, 2017; Manyoe, 2019; Manyoe and Bahutalaa, 2017; Tolodo et al., 2019).

Gorontalo, which is located in the North Arm of Sulawesi, Eastern Indonesia, is influenced by the macro and micro plates, namely Eurasian, Indian-Australian and Pacific-Philippines (Hall and Wilson, 2000). The Pacific and Philippine plates move in the direction of WNW crashing into the Eurasian plate at a speed of $9 \mathrm{~cm} / \mathrm{yr}$ (Hinschberger et al., 2005).

Banggai-Sula microcontinent is located in the SE part of the North Arm of Sulawesi. Banggai-Sula microcontinent is a fragment from Australia (Hall, 2002). Banggai-Sula move to the west because of the Sorong Fault movement. A collision occurred between Banggai-Sula microcontinent with North East Arm Sulawesi. This causes North Arm Sulawesi to rotate $20^{\circ}$ clockwise and causes subduction in the Sulawesi Sea (Hinschberger et al., 2005).
The Libungo geothermal area is a geothermal area in Suwawa which has a high temperature of the hot springs among other geothermal areas in Suwawa (Manyoe, 2019; Manyoe and Bahutalaa, 2017; Suleman and Angsari, 2005; Tolodo et al., 2019). The Libungo geothermal area is composed of Bilungala Volcanics (Tmbv), Bone Diorite (Tmb), Pinogu Volcanics (TQpv), Reef Limestone (Q1) and Lake Deposits (Qpl) (Apandi and Bachri, 1997). Bilungala Volcanic Arcs are formed below sea level. Sula's micro fragment collide into an arc and stops the magmatisme associated with the Bilungala Arc. New volcanic activity occurs from different tectonic events and produces Pinogu Volcanics (Hamilton, 1979; Moore and Silver, 1983; Perelló, 1994).

Manyoe (2019)studies the Libungo area based on geological conditions. Suleman and Angsari (2005)studied geochemistry in the Libungo area while Direktorat Panas Bumi (2017) investigated through geomagnetic, gravity, and electrical methods. The gradient thermal welldrilling in the geothermal area of Libungo conducted by (Nanlohi and Risdianto, 2006).

Manyoe's research can show the surface lithology of the Libungo area (Manyoe, 2019). Suleman and Angsary's research can show reservoir fluid characteristics (Suleman and Angsary, 2005). Directorate Panas Bumi (2017) research can show deep subsurface interpretations. However, there is no research in the Libungo geothermal area that discusses the details of shallow subsurface conditions that can model the distribution of lithology in the shallow subsurface areas in Libungo.

Shallow subsurface can be identified using the resistivity method (Suryadi et al., 2018). Resistivity methods have an important role in geothermal studies. Circulation of hot fluid at subsurface affects the resistivity properties of geological 
formations in geothermal areas (Thanassoulas, 1991). The general resistivity method and the Schlumberger configuration resistivity method that will be used by researchers can create shallow subsurface and deep subsurface models (Chabaane et al., 2017; El-Qady, 2006; Islami, 2019; Suryadi et al., 2018; Teftae et al., 2019).

Volcano-tectonic processes in the Libungo area can be the cause of the presence of geothermal potential. It is very interesting to examine shallow subsurface conditions in the research areathat are not explained in detail in previous studies. This research aims to create a shallow subsurface model in the hot springs area of the Libungo geothermal based on resistivity data.This research is useful to show the media spread of the fluid in the shallow subsurface so that it can be the basis for the development of direct utilization of geothermal potential in the Libungo around the hot springs area.

\section{Methods}

\subsection{Research Location}

Data was collected in the Libungo geothermal area. Administratively, the Libungo geothermal area is located in the South Suwawa District, Bone Bolango Regency, Gorontalo Province.

The north of research area is bordered by the valley of the Bone River. The south is bordered by the southern volcanic hills. East side is bordered by southern volcanic hillsides. The west is bordered by the southern volcanic hillsides. Regionally, the research area is composed of volcanic rocks, plutonic rocks and sedimentary rocks (Fig. 1).

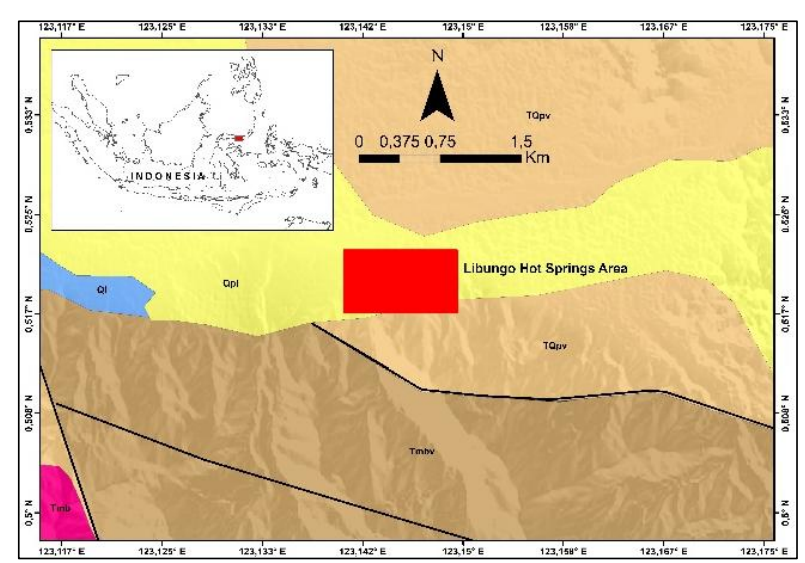

Fig.1. Regional geology of research location (Apandi and Bachri, 1997).

Bone Diorite (Tmb) is composed of granite, granodiorite and diorite. Bilungala Volcanics (Tmbv) is composed of basalt, breccia, andesite lava, tuff, dacite and rhyolite. Bilungala Volcanics (Tmbv) is entirely composed of volcanic rock. Bone Diorite (Tmb) is interpreted as being comagmatic towards Bilungala Volcanics (Apandi and Bachri, 1997; Bachri, 2006; Perelló, 1994).

Pinogu Volcanics (TQpv) is composed of breccias, tuffs and lava. Reef Limestone (Ql) is composed of clastic limestone and reef limestone. Lake Deposits (Qpl) is composed of claystone, sandstone and gravel (Apandi and Bachri, 1997; Perelló, 1994).

Bilungala Volcanics (Tmbv) and Bone Diorite (Tmb) formed in the Middle Miocene to Early Pliocene. Pinogu Volcanics (TQpv) are formed in Late Pliocene to Early Pliocene while Reef Limestone (Q1) and Lake Deposits (Qpl) are formed in Plio-Plistocene and uplift (Bachri, 2006).

\subsection{Data Collection}

Resistivity data acquisition is carried out around the Libungo hot springs, namely the Libungo hot spring 1 and the Libungo hot spring 2 . The Libungo hot spring 1 is at coordinates $0.5195^{\circ} \mathrm{N}$ and $123.1447^{\circ} \mathrm{E}$. The Libungo hot spring 2 is at coordinates $0.5213^{\circ} \mathrm{N}$ and $123.1448^{\circ} \mathrm{E}$ (Fig. 2).

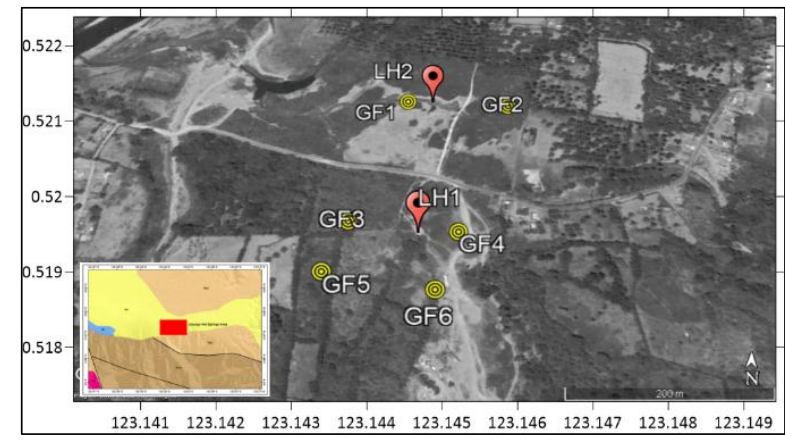

Fig.2. Electrical station survey. GF1 till GF6 are electrical station point. LH1 and LH2 are Libungo hot springs point.

The instrument used for resistivity data acquisition is the IPMGEO-4200 resistivity meter. GF1 points are at coordinates $0.5212^{\circ} \mathrm{N}$ and $123.1445^{\circ} \mathrm{E}$ while GF2 points are at coordinates $0.5211^{\circ} \mathrm{N}$ and $123.1457^{\circ} \mathrm{E}$. GF3 points are at coordinates $0.5195^{\circ} \mathrm{N}$ and $123.1439^{\circ} \mathrm{E}$ while GF4 points are at coordinates $0.5194^{\circ} \mathrm{N}$ and $123.1451^{\circ} \mathrm{E}$. GF5 points are at coordinates $0.5189^{\circ} \mathrm{N}$ and $123.1437^{\circ} \mathrm{E}$ while GF6 points are at coordinates $0.5187^{\circ} \mathrm{N}$ and $123.1449^{\circ} \mathrm{E}$.

The electrode configuration used is the Schlumberger configuration. A and B electrodes are current electrodes. $\mathrm{M}$ and $\mathrm{N}$ electrodes are potential difference electrodes. $\mathrm{L}$ is the distance of $\mathrm{AB} / 2$ and 1 is the distance of MN/2 (Fig. 3).

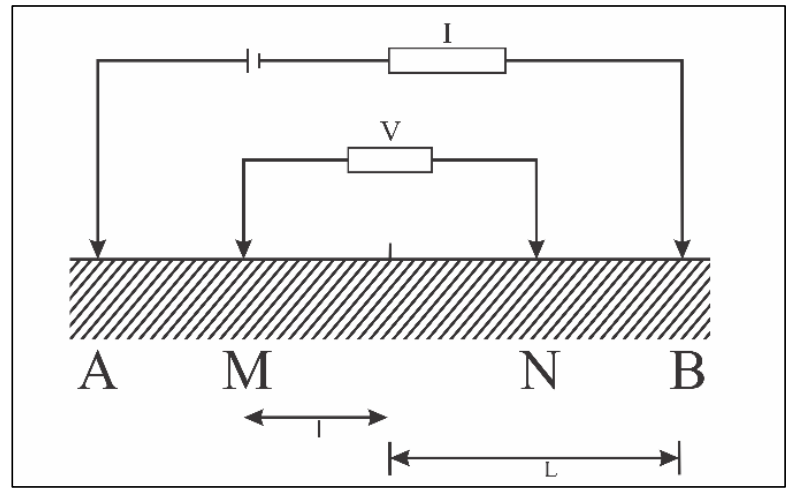

Fig. 3. Schlumberger electrode configuration (Adapted from Santoso, 2002).

The direction of the array is east-west direction. Electric current is injected into the subsurface through a current electrode and the distribution of the potential difference is measured by the potential difference electrode. The measurement starts from the middle of the array to both ends of the array by changing the distance between the electrodes.

\subsection{Data Processing and Interpretation}

Data obtained from the results of the acquisition are current data (I) in units of $\mathrm{mA}$ and potential difference data $(\mathrm{V})$ in units of $\mathrm{mV}$. Additional data used to determine variations in resistivity are geometric factors $(\mathrm{K})$.

Current electrodes and potential electrodes have moved from the center to the end of the array during the data acquisition process. The removal of these electrodes follows the Schlumberger electrode configuration. Therefore, it is necessary to calculate the geometry factor to correct the 
electrode configuration using Eqn. (1). Where $\mathrm{L}$ is the distance of $\mathrm{AB} / 2$ and 1 is the distance of $\mathrm{MN} / 2$.

$\mathrm{K}=\frac{\pi\left(\mathrm{L}^{2}-1^{2}\right)}{21}$

After calculating the geometry factor, the calculation of the resistivity value $(\rho)$ is then performed. Calculation of the resistivity value by entering the data of current (I), potential difference (V) and geometry factors (K) using Eqn. (2). $\rho=K \frac{\mathrm{V}}{\mathrm{I}}$

The thickness of the subsurface layers is obtained by plotting variations of resistivity value versus depth in curve Based on variations of resistivity value versus depth, interpretation of subsurface layers using resistivity values by Hunt (2005); Mori (2003); Telford W.M, Geldart L.P (1990); Wintolo et al., (2017) with regard to the geology of the research area (Table 1). The results are displayed in the form of a single log, lithology fence and 3D lithology model using Rockworks 16.

Table 1. Resistivity value of materials (Hunt, 2005; Mori, 2003; Telford W.M, Geldart L.P, 1990; Wintolo et al., 2017).

\begin{tabular}{clc}
\hline No & \multicolumn{1}{c}{ Material } & Resistivity $(\Omega \mathrm{m})$ \\
\hline 1 & Silty clay & $3-150$ \\
2 & Clay & $1-100$ \\
3 & Sandstone & $50-500$ \\
4 & Volcanic breccia & $90-290$ \\
5 & Tuff & $5-14$ \\
6 & Andesite & $100-2000$ \\
7 & Granite & $1000-10000$ \\
8 & Diorite & $10^{4}-10^{5}$ \\
9 & Basalt & $10-1.3 \times 10^{7}$ \\
& Bedrock: well fractured to & $150-300$ \\
10 & slightly fractured with moist & \\
& material in cracks & $300-2400$ \\
11 & Bedrock : slightly fractured & with dry material in cracks \\
\hline
\end{tabular}

\section{Result and Discussion}

The variation of resistivity versus depth is displayed in the form of single log, lithology fence and lithology model. Single log displays lithology distribution based on depth at each resistivity data collection point. Lithology fence displays lithology distribution patterns around the Libungo hot springs.

The lithology model displays a shallow subsurface model of the Libungo geothermal region, an explanation of the physical properties of the subsurface of each lithology based on resistivity. Lithology symbol and color by Apandi and Bachri (1997) and Victorine (2008) used in single log, lithology fence and lithology models (Fig. 4).

\begin{tabular}{|ll|}
\hline \multicolumn{1}{|c|}{ Lithology } \\
\hline Soil \\
\hline Silty Clay \\
\hline Clay \\
\hline Breccia \\
\hline Andecite \\
\hline
\end{tabular}

Fig.4. Lithology simbols and colors (Apandi and Bachri, 1997 Victorine, 2008)

Single $\log$ GF1 reaches a maximum depth of $20.61 \mathrm{~m}$ (Fig. 5). Single log GF1 consists of three layers, namely soil, silty clay and volcanic breccia. Soil as the first layer, silty clay as the second layer and volcanic breccia as the third layer.

The soil is at a depth of $0-0.84 \mathrm{~m}$ with a thickness of 0.84 $\mathrm{m}$. Silty clay is at a depth of $0.84-15.49 \mathrm{~m}$ with a layer thickness of $14.65 \mathrm{~m}$. Volcanic breccia is at a depth of 15.49 . $20.61 \mathrm{~m}$ with a thickness of $5.12 \mathrm{~m}$. Based on regional stratigraphy, silty clay is synchronized with Lake Deposits $(\mathrm{Qpl})$ and volcanic breccia is equivalent to Pinogu Volcanics (TQpv).
Single log GF2 reaches a maximum depth of $25 \mathrm{~m}$ (Fig. 6). Single log GF2 is near Libungo hotspring 2 . Soil as the first layer is at a depth of $0-0.60 \mathrm{~m}$ with a thickness of $0.60 \mathrm{~m}$. Starting from a depth of $0.60-11.94 \mathrm{~m}$, there are alternates between clay and silty clay. Clay is at a depth of $0.60-0.71 \mathrm{~m}$ with a layer thickness of $0.11 \mathrm{~m}$. The next layer is occupied by silty clay which is at a depth of $0.71-1.64 \mathrm{~m}$ with a thickness of $0.93 \mathrm{~m}$. At a depth of $1.64-3.64 \mathrm{~m}$, a layer of clay with a thickness of $1.99 \mathrm{~m}$ is found. The next layer is silty clay which is at a depth of $3.64-11.96 \mathrm{~m}$ with a thickness of $8.3 \mathrm{~m}$. Volcanic breccia in the next layer is at a depth of $11.94-25 \mathrm{~m}$ with a thickness of $13.06 \mathrm{~m}$. Based on regional stratigraphy, silty clay is synchronized with Lake Deposits (Qpl) while volcanic breccia is equivalent to Pinogu Volcanics (TQpv).

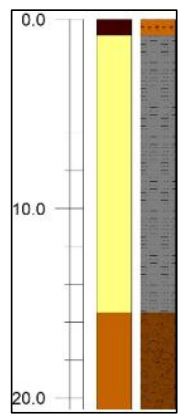

Fig 5. Single $\log$ GF1

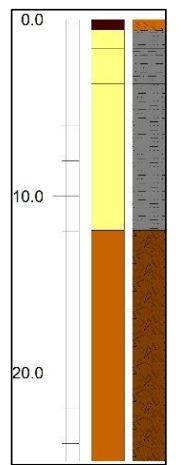

Fig 6. Single log GF2.

Single $\log$ GF3 reaches a maximum depth of $20.41 \mathrm{~m}$ (Fig. 7). Single log GF3 consists of three layers, namely soil in the first layer, silty clay in the second layer and volcanic breccia in the third layer. The soil is at a depth of $0-1 \mathrm{~m}$ with a thickness of $1 \mathrm{~m}$. Silty clay is at a depth of $1-5.21 \mathrm{~m}$ with a layer thickness of $4.22 \mathrm{~m}$. Volcanic breccia is at a depth of 5.21 . $20.41 \mathrm{~m}$ with a thickness of $15.2 \mathrm{~m}$. Referring to regional stratigraphy, silty clay is equivalent to Lake Deposits $(\mathrm{Qpl})$ and volcanic breccia is equivalent to Pinogu Volcanics (TQpv).

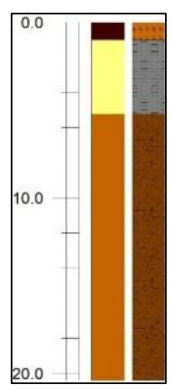

Fig 7. Single $\log$ GF3

The maximum depth that can be achieved in a single log of GF4 is $20.22 \mathrm{~m}$ (Fig. 8). Single log GF4 is near Libungo hot spring 1 . Soil is at a depth of $0-1.03 \mathrm{~m}$. There is clay at a depth 
of $1.03-3.23 \mathrm{~m}$. Silty clay is at a depth of $3.23-6.61 \mathrm{~m}$. Volcanic breccia is in the lower layer at a depth of $6.61-20.22$ $\mathrm{m}$. Referring to regional stratigraphy, silty clay is equivalent to Lake Deposits (Qpl) while volcanic breccia is equivalent to Pinogu Volcanics (TQpv).

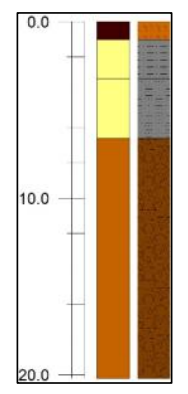

Fig 8. Single log GF4.

Single log GF5 reaches a maximum depth of $20.61 \mathrm{~m}$ (Fig. 9). The soil was found at depth $0-1.61 \mathrm{~m}$. Under the soil layer, silty clay is found at a depth of $1.61-3.65$. The next layer is volcanic breccia which is at a depth of $3.65-11.87 \mathrm{~m}$. The lowest layer is andesite which is at a depth of $11.87-20.61 \mathrm{~m}$. Silty clay is equivalent to Lake Deposits (Qpl) while volcanic breccia and andesite are equivalent to Pinogu Volcanics (TQpv). The equalization is based on the regional stratigraphy of the research area.

Single log GF6 reaches a maximum depth of $20.22 \mathrm{~m}$ (Fig. 10). Single log GF6 consists of four layers, namely soil in the first layer, silty clay in the second layer, volcanic breccia in the third layer and andesite in the fourth layer. The soil is at a depth of $0-1.23 \mathrm{~m}$. Silty clay is at a depth of $1.23-2.57 \mathrm{~m}$. Volcanic breccia is at a depth of $2.57-12.86 \mathrm{~m}$ with a thickness of 10.3 m.

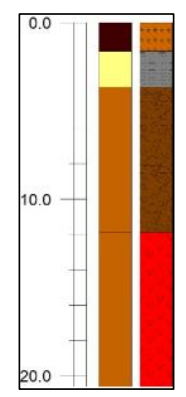

Fig 9. Single log GF5.

Andesite is at a depth of $12.86-20.22 \mathrm{~m}$ with a thickness of $7.36 \mathrm{~m}$. Andesite in the research area began to appear at the point of GF5 and at the point GF6. Referring to regional stratigraphy, silty clay is synchronized with Lake Deposits (Qpl). Referring to regional stratigraphy, volcanic breccia and andesite are equivalent to Pinogu Volcanics (TQpv).

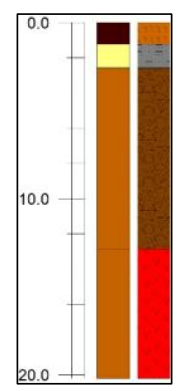

Fig 10. Single log GF6.
GF1 - GF6 fence lithology shows the pattern of lithological distribution around the Libungo hot springs (Fig. 11). GF1 and GF2 are located in the north. GF3 and GF4 are located in the middle. GF5 and GF6 are located in the southern part. Silty clay dominates the northern area around the Libungo hot springs. Volcanic breccia is identified in all areas stretching from north to south. Volcanic breccia is getting thicker towards the south. In the south the GF5 and GF6 are marked by the appearance of andesite.

Silty clay, which at some point is in alternate with clay, is getting thicker to the north. This is influenced by the presence of the Bone River in the north. The northern part of the research area, regionally also included in the Lake Deposits $(\mathrm{Qpl})$. The presence of clay and silty clay thickened to the north is interpreted to be influenced by these two things. Volcanic breccia is getting thicker to the south. The appearance of andesite in the south can be explained by the presence of southern mountains which are mostly composed of quarternary volcanic rocks namely Pinogu Volcanics (TQpv).

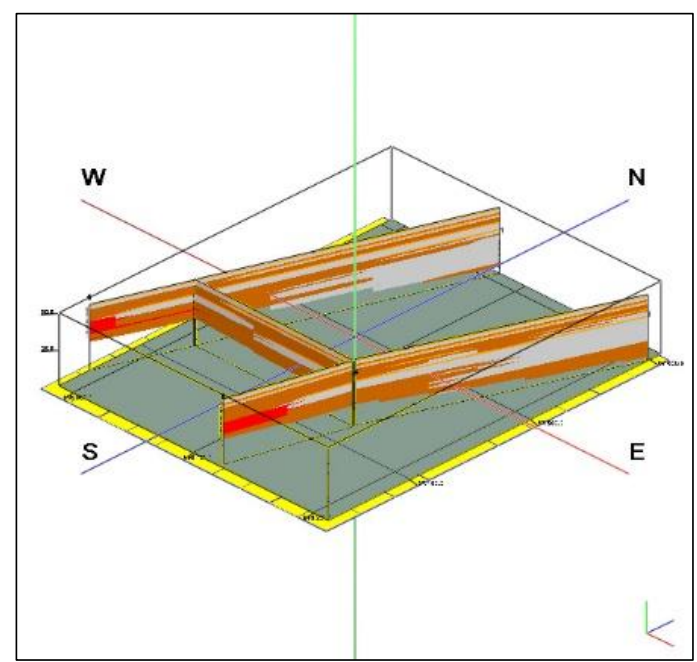

Fig 11. Litologi fence that shows lithology distribution of GF1 - GF6.

According to Nanlohi and Risdianto (2006), shallow fractures due to tectonics around the Libungo hot springs were not found. The heat from the reservoir is transmitted to the surface by the physical properties of porous and permeable rocks. Shallow subsurface modeling can show the porous and permeable lithology distribution which is a way to heat and fluid to the surface.

The lithology of the research area is composed of andesite, volcanic breccia, silty clay and clay (Fig. 12). According to Earle (2015), andesite is a volcanic rock which has fractures and does not have fractures. Percentage of fractures in andesite are around $0-50 \%$, start from unfracture andesite to fracture andesite.High resistivity in the Libungo geothermal area is 320$349 \Omega \mathrm{m}$. This high resistivity is interpreted as andesite. According to Hunt (2005), the resistivity of $320-349$ is a lithology that has a slightly fracture with dry material as a fracture filler.

Based on this classification, andesite in the Libungo geothermal area is an andesite which has slightly fractures and is andesite dry. The fracture was not found in the shallow subsurface of the Libungo area, according to Nanlohi and Risdianto (2006), but based on the resistivity value it was found that there was a fracture in andesites in the Libungo geothermal area. Andesites in the Libungo geothermal area can transfer heat from the reservoir. Heat transfer by shallow subsurface rocks is similar to research by Nanlohi and Risdianto (2006), 
but based on the interpretation of resistivity, andesite cannot transfer fluid.

Volcanic breccia are rocks that composed of angular fragments and are the result of brecciation or depositional environments due to volcanic activity (Bowes, 1989). Volcanic breccia has good porosity and permeability (Zou, 2013). Medium resistivity in the Libungo geothermal area is 177-194 $\Omega \mathrm{m}$. This medium resistivity is interpreted as volcanic breccia.

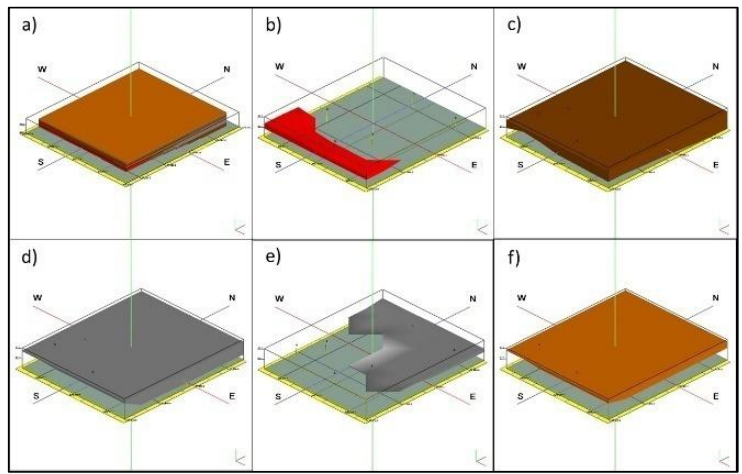

Fig.12. Lithology distribution models in the Libungo hot springs. a) Lithology model 3D; b) Litology isopach 3D andesite; c) Litology isopach 3D volcanic breccia; d) Litology isopach 3D silty clay; e)

Litology isopach 3D clay; and f) Litology isopach 3D soil.

According to Hunt (2005) resistivity $177-194 \Omega \mathrm{m}$ is a lithology that has a well to slightly fracture with moist material as a filler. Based on this, volcanic breccia in the Libungo geothermal area has well to slightly fractures and is a volcanic breccia moist. Volcanic breccia in the Libungo geothermal area can transfer heat from the reservoir as researched byNanlohi and Risdianto (2006). Based on the resistivity interpretation, volcanic breccia can also transfer fluid to the surface because it has fractures.

Silty clay has a porosity of 36-79\% (Earle, 2015). Silty clay has good porosity and permeability so that it can be a medium of heat and fluid to the surface in the Libungo geothermal area. This is supported by the resistivity value of silty clay which is in the range of 3.25-37.9 $\Omega \mathrm{m}$. According toHunt (2005), silty clay and lithology containing silty with resistivity values below $75 \Omega \mathrm{m}$ have wet-moist physical properties.

Clay resistivity value in the research area is in the range 1.56-2.78 $\Omega \mathrm{m}$. According to Hunt (2005) the resistivity value in the range $1.56-2.78 \Omega \mathrm{m}$ is the resistivity value for wet-moist clay. According toEarle (2015), clay is a material that has good porosity but has poor permeability. Therefore, clay in the Libungo geothermal area has good porosity as evidenced by resistivity values that show wet-moist physical properties but cannot transfer fluids properly to the surface.

Based on the shallow subsurface model, the Libungo geothermal area is composed of andesite, volcanic breccia, silty clay and clay. Andesites are concentrated in the southern part of the Libungo geothermal area, characterized by high resistivity. Volcanic breccia spread from the north to the south of the research area. Volcanic breccia is getting thicker to the south marked with a medium resistivity value. Silty clay is spread from north to south of the research area. Silty clay is getting thicker to the north marked by a low resistivity value. Clay is scattered in the middle of the northern part of the Libungo geothermal area characterized by very low resistivity.

\section{Conclusion}

The shallow subsurface of the Libungo geothermal area is composed of andesite, volcanic breccia, silty clay and clay.
Andesite occupies the southern part of the study area. Volcanic breccias occupy the northern to southern parts of the research area. Silty clay occupies the entire research area. Silty clay is getting thicker to the north and volcanic breccia is getting thicker to the south. Clay occupies the middle of the north of the research area. The highest resistivity value in the research area is andesite resistivity values ranging between $320-349 \Omega \mathrm{m}$. The medium resistivity value is the volcanic breccia resistivity value which ranges between $177-198 \Omega \mathrm{m}$. Low resistivity value is the resistivity value of silty clay which ranges from 3.25-37.9 $\Omega \mathrm{m}$. The very low resistivity value is the clay resistivity value which ranges between 1.56-2.78 $\Omega \mathrm{m}$.

Andesites in the research area have fractures, but andesites are not a fluid path to the surface. Volcanic breccias have fractures. Fractures in volcanic breccias provide fluid to the surface. Clay and silty clay in the research area are wet to moist but only silty clay is able to transfer fluids properly to the surface. Based on resistivity data, the accumulation of geothermal fluid in the Libungo area is located in the northern part of the research area in volcanic breccia, silty clay and clay.

Therefore, direct use of geothermal in the hot springs area of Libungo geothermal, it is recommended to be carried out in the northern part by considering the availability of fluid in the shallow subsurface. As for proving that the shallow subsurface fractures in andesite are due to the effects of tectonics, it is necessary to investigate the geological structure in the research area.

\section{Acknowledgments}

The authors would like to thank to the Research and Community Service Center of Universitas Negeri Gorontalo for funding this research. Thank you to Geodiversity team and staff of the Geology Engineering Laboratory of Universitas Negeri Gorontalo for helping with data collection in the field.

\section{References}

Apandi, T., Bachri, S., 1997. Peta Geologi Lembar Kotamobagu, Sulawesi. Pusat Penelitian dan Pengembangan Geologi, Bandung.

Bachri, S., 2006. Stratigrafi lajur volkano-plutonik daerah gorontalo, sulawesi. J. Geol. dan Sumberd. Miner. XVI, 94-106.

Bowes, D.., 1989. Petrology, Boston. Springer, Boston, MA, Boston.

Direktorat Panas Bumi, 2017. Potensi Panas Bumi Indonesia, Direktorat Panas Bumi Direktorat Jenderal Energi Baru, Terbarukan dan Konservasi Energi Kementerian Energi dan Sumber Daya Mineral.

Chabaane, A., Redhaounia, B., Gabtni, H., 2017. Combined application of vertical electrical sounding and 2D electrical resistivity imaging for geothermal groundwater characterization: Hammam Sayala hot spring case study (NW Tunisia). J. African Earth Sci. 134 , https://doi.org/10.1016/j.jafrearsci.2017.07.003

Earle, S., 2015. Physical Geology. BCcampus, Victoria B.C.

El-Qady, G., 2006. Exploration of a geothermal reservoir using geoelectrical resistivity inversion: Case study at Hammam Mousa, Sinai, Egypt. J. Geophys. Eng. 3, 114 121. https://doi.org/10.1088/1742-2132/3/2/002

Hall, R., 2002. Cenozoic geological and plate tectonic evolution of SE Asia and the SW Pacific: Computer-based reconstructions, model and animations. J. Asian Earth Sci. 20, 353-431. https://doi.org/10.1016/S13679120(01)00069-4

Hall, R., Wilson, M.E.J., 2000. Neogene sutures in eastern 
Indonesia. J. Asian Earth Sci. 18, 781-808. https://doi.org/10.1016/S1367-9120(00)00040-7

Hamilton, W., 1979. Tectonics of the Indonesian Region. Bull. Geol. Soc. Malaysia 6, 3-10.

Hinschberger, F., Malod, J.A., Réhault, J.P., Villeneuve, M., Royer, J.Y., Burhanuddin, S., 2005. Late Cenozoic geodynamic evolution of eastern Indonesia. Tectonophysics 404, 91-118. https://doi.org/10.1016/j.tecto.2005.05.005

Hunt, R.E., 2005. Geotechnical Engineering Investigation Handbook, Second Edition, CRC Press. Taylor \& Francis.

Islami, N., 2019. Weak Soil Investigation at The Slope Zone in The Hot Spring Area, Rokan Hulu , Indonesia. J. Geosci. Eng. Environ. Technol. 4, 236-241. https://doi.org/10.25299/jgeet.2019.4.4.4258

Manyoe, I.N., 2019. Geologi dan Manifestasi Thermal Libungo. UNG Press, Gorontalo.

Manyoe, I.N., Bahutalaa, I., 2017. Kajian Geologi Daerah Panas Bumi Lombongo Kabupaten Bone Bolango Provinsi Gorontalo. J. Geomine 5. https://doi.org/10.33536/jg.v5i1.92

Moore, G.F., Silver, E.A., 1983. Collision Processes in the Northern Molucca Sea. Tecton. Geol. Evol. Southeast Asian Seas Islands. Am. Geophys. Union, Geophys. Monogr., 27, 360-372. https://doi.org/10.1029/GM027p0360

Mori, K., 2003. Hidrologi untuk Pengairan/ Manual on Hydrology, 9th ed. PT. Pradnya Paramita, Jakarta, Indonesia.

Nanlohi, F., Risdianto, D., 2006. Pemboran Sumur Landaian Suhu SWW-1 Lapangan Panas Bumi Suwawa Kabupaten Bonebolango - Gorontalo, in: Pemaparan Hasil Kegiatan Lapangan Dan Non Lapangan Tahun 2006, Pusat Sumber Daya Geologi.

Perelló, J.A., 1994. Geology, porphyry $\mathrm{CuAu}$, and epithermal $\mathrm{CuAuAg}$ mineralization of the Tombulilato district, North Sulawesi, Indonesia. J. Geochemical Explor. 50,
221-256. https://doi.org/10.1016/0375-6742(94)900264

Santoso, D., 2002. Pengantar Teknik Geofisika. Penerbit ITB, Bandung.

Suleman, B., Angsari, 2005. Geokimia Daerah Panas Bumi SUwwa Kab. Bone Bolango-Gorontalo, in: Pemaparan Hasil Kegiatan Lapangan Subdit Panas Bumi.

Suryadi, A., Putra, D.B.E., Kausarian, H., Prayitno, B., Fahlepi, R., 2018. Groundwater exploration using Vertical Electrical Sounding (VES) Method at Toro Jaya, Langgam, Riau. J. Geosci. Eng. Environ. Technol. 3, 226-230. https://doi.org/10.24273/jgeet.2018.3.4.2226

Teftae, O.Y.K., Maryanto, S., Santoso, D.R., 2019. 3D Vertical Electrical Sounding ( VES ) At Mount Pandan Hot Springs Area, East Java, Indonesia. Int. J. Innov. Sci. Eng. Technol. 6, 5 p.

Telford W.M, Geldart L.P, S.R.E., 1990. Applied geophysics, Second Edi. ed. Cambridge University Press, Cambridge.

Thanassoulas, C., 1991. Geothermal exploration using electrical methods. Geoexploration 27, 321-350. https://doi.org/10.1016/0016-7142(91)90005-W

Tolodo, D.D., A. Usman, F.C., Manyoe, I.N., Gaib, F.A., Putje, F.H., Ibrahim, Y., 2019. Geologi Daerah Geothermal Pangi Kabupaten Bone Bolango Provinsi Gorontalo. Jambura Geosci. Rev. 1, 22. https://doi.org/10.34312/jgeosrev.v1i1.2035

Victorine, J.R., 2008. Lithology Symbols. Kansas Geological Survey, Kansas.

Wintolo, D., Arifianto, I., Wibowo, J.P., 2017. Resistivity Survey for Groundwater Explorationin Tiron Village, Kediri, East Jawa, in: Peran Penelitian Ilmu Kebumian Dalam Pembangunan Infrastruktur Di Indonesia.

Zou, C., 2013. Volcanic Reservoirs in Petroleum Exploration. Elsevier Inc.

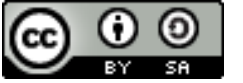

(C) 2020 Journal of Geoscience, Engineering, Environment and Technology. All rights reserved. This is an open access article distributed under the terms of the CC BY-SA License (http://creativecommons.org/licenses/by-sa/4.0/). 